\title{
INTEGRATING THE VALUE OF ECO-BUILDING WITHIN THE DESIGN PROCESS: AN INTRODUCTION TO ASSESSING CRITERIA IN EGYPT
}

\author{
Hatem Galal Abd Elazim Ibrahim, Assistant Professor \\ Department of Architecture, Faculty of Engineering, Mataria, Helwan \\ University \\ Postal Code: 11718 MASAKEN ELHELMIA, Cairo-Egypt \\ E-Mails: hatem_ibrahim@hotmail.com
}

(Received February 16, 2006 Accepted April 13, 2006)

\begin{abstract}
High performance eco-building offer superior performance in a variety of areas, including functionality, energy and water efficiency, quality of the indoor environment (air quality, thermal comfort, lighting...etc.), waste management and other many areas without necessarily increasing in capital costs. Establishing challenging building performance objectives should be at very early in the design process, usually by referencing a recognized rating system. This rating system has been done and identified in Europe, United States of America and many other countries. This piece of work introduces the idea of constructing an eco-building assessing tool for Egypt by introducing a definition of ecobuilding issue and its components. It discusses the barriers that prevent qualifying the eco-building scheme. This paper illustrates two famous schemes that used in assessment the eco-scheme in buildings, the first one used in the United States of America called LEED and the second one used in New Zealand and Australia called BRANZ. The strategy of development and delivery of the Egyptian eco-assessing tools to be concluded. These tools are depending on the basic criteria of qualifying the eco-building. The quantity of the used data is depending on the awareness of the developers, decision makers, and the construction organizations and their understanding to the value of qualifying the eco-building in projects. According to this, more data can be used in the assessing tools which lead to a positive effect on the performance of the building.
\end{abstract}

\section{INTRODUCTION}

Eco-building is defined as a collection of land-use, building design, and construction strategies that reduces negative environmental impacts. It involves analyzing interconnected issues as site, climate, orientation, lighting, thermal comfort, materials, and optimizing all those aspects in an integrated design. To capture the multiple benefits, the "whole system" design process must occur early in the building's conception and must involve teamwork. Working together can produce "big picture" 
visions that can one solution to a problem to create many more solutions often at no additional costs. It is precisely the integrated approach that allows many eco-buildings to cost no more than standard buildings, even though some of their components may cost more. Eco-design elements may each serve several functions and allow other building components to be downsized. For example, better windows and insulation can allow for smaller heating systems. Eco-building is the latest step in the evolution of energy-efficient design and construction, addressing the importance of reducing our impact on earth, accordingly, there are huge number of countries that established its own eco-assessing tools to be able to assemble buildings with environmentally appropriate materials; and incorporating energy efficiency and renewable energy systems. From this point of view, this paper presents innovative efforts that analyze, quantify and develop the Egyptian eco- building assessing tools.

\section{UNDERSTANDING ECO-BUILDING}

Eco-building is a phrase for the current trend toward better use of renewable and recycled building materials such as wood, clay products (brick), gypsum products and even asphalt in parking lots. The naturally occurring materials take less energy to produce compared to steel, aluminium, glass and plastic. Another adaptation of these design principles are building solutions whose its primary goal is reducing building energy consumption. In order to qualify eco-building, a building should adapt part of its energy usage from sunlight and/or wind energy. Less costly systems may include correct window placement for maximum day lighting, reducing lighting costs, window shading and tinted glass. This will reduce heat gain and lower air conditioning costs. Low water volume is also a method to ease operation costs and the environmental burden. Even material colours such as white roofing will reflect heat and reduce cooling costs. These are the basics concepts that can be applied to one degree or another to produce better buildings. But, in order to be able to qualify eco-building, it is the smart combination of these principles into one cohesive design that will lower the environmental load while enhancing building usability.

\subsection{The Importance of Eco-Building}

All decision makers, building owners, tenants, architectural firms or construction companies must become aware of the importance of eco-architecture to minimize adverse environmental impacts. (Peter Davey, 1997) [1] Writes:

If we continue to oppose natural forces to the extent we are doing now, the planet will simply change to make human life vastly unpleasant, or perhaps even impossible. Everyone has some responsibility for trying to avert this quite likely and imminent future - none more so than those who design the man-made environment, who if they use imagination responsibly, will begin to evolve new architectures and forms of planning which will draw on ancient wisdom and modern technology alike to help humanity live in harmony with nature.

It is argued that the approach of eco-building has many benefits. In the case of a large office, for example, the combination of eco-design techniques and clever technology can not only reduce energy consumption and environmental impact, but also reduce running costs, create a more pleasant working environment, improve employees' health and productivity, reduce legal liability, and raise property values 
and rental returns. The majority of respondents support the eco-home scheme; they stated that qualifying the scheme is very useful. A green building education and health care agencies [2] are of great importance. The importance of qualifying eco-building scheme for developer, users, community and environment are as follows:

For building owner-developers:

- Much lower operating costs (energy, water, maintenance).

- Enhanced marketability and higher return on assets.

For building users:

- Functional, healthy, safe and comfortable indoor environments that contribute to program outcomes through:

- increased worker productivity.

- a competitive edge in attracting and retaining skilled workers.

- better health outcomes in health care facilities.

- better learning outcomes in educational facilities.

For the community:

- Smaller demands on the local infrastructure (e.g., energy and water utilities, transportation, etc.)

- Increased local economic activity.

For the environment:

- Efficient use of resources and reduced waste/greenhouse gases.

- Low site impacts.

All without necessarily increasing capital costs.

\subsection{Components of Eco-Building}

figure 1.

(Jason, 1996) [3] Classified the eco-architecture into six components as seen in

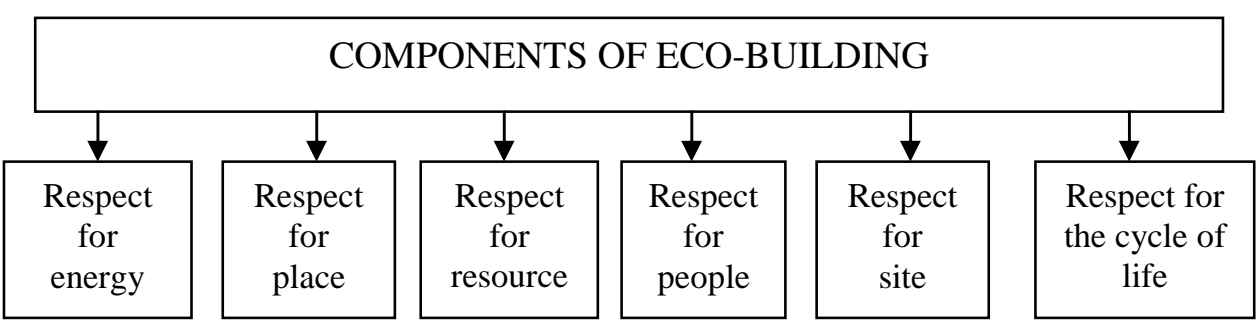

Figure 1: Components of eco-building according to Jason [3].

A brief illustration for each component as follows:

1. Respect for Energy - Minimize buildings requirements for energy consumption. Reduce the need for electric lighting, air conditioning, and heating. Design to support renewable energy. Use materials that are low in embodied energy, both in manufacture and distribution. 
2. Respect for Place - Work with local climate, context and materials to produce an architecture that fits comfortably into its man made and natural surroundings. This component helps maintain regional differences, which instil pride of place while supporting local economies.

3. Respect for Resources - Minimize man-made resources used in a building. Build smaller and design for more efficient use of space. Remove elements of a program that are truly unneeded. Build for longevity. Use renewable materials.

4. Respect for People - Build with materials that are non-toxic and do not contribute to an unhealthy indoor air quality. Do not build with materials that, in any stage of their use from manufacture to installation, cause damage to people. Build to empower people in their daily activities regardless of age or physical abilities. Wherever possible, build beautifully.

5. Respect for site - Preserve the character of both natural and man-made features of any site. Repair and restore damaged areas of the site. Maintain the local ecosystems ability to sustain itself in the future. Do not build in sensitive areas.

6. Respect for the cycle of life - Abolish the use of any material that cannot be safely broken down by natural processes and used as 'food'. Abolish the use of any material that greatly endangers people or the natural environment.

\subsection{Barriers To Developer For Qualifying Eco-Buildings}

It is important for the developer to be able to define the barriers that effect the fulfilling of eco-building during the design process phase.

The main barriers for qualifying eco-home scheme can be briefed in the following points:

1- Lack of publicity about the awareness of eco-design.

2- The extra time commitment required by designer/architect.

3- Perceived extra cost of incorporating eco-design attributes.

4- Lack of interest by architects, developers, homeowners and decision makers in environmental issues in general.

5- Lack of support from government.

6- Lack of understanding of the benefits of eco-building. It is still seen as an unnecessary activity with little practical benefits.

\section{ESTABLISHING ECO-ASSESSING TOOLS FOR EGYPT}

As many countries in the world, Egypt has to establish its eco-building rating system that can evaluate the qualifying of eco-building criteria in the different type of projects. These criteria should be applied to future development, new building, expansion projects, and modifications to historic buildings.

\subsection{Existing Development Tools For Assessing Eco-Building}

There are many eco-building assessing tools that are considered in designing and evaluating of buildings.

EcoLogo is North America's most widely recognized and respected multiattribute environmental certification mark. By certifying the environmental leaders in 
over 300 categories of products, EcoLogo helps environmental marketers win customers, and helps buyers - both consumer and corporate - find and trust the world's most sustainable products [4].

There is also a certification system which is established for sustainable tourism development in Europe, the aim of this certificate to provide tourist destinations and their stakeholders with quality assessed information on sustainable tourism and how to do in practice [5].

The Green Communities Criteria also established in the United States of America, which promote public health, energy conservation, operational savings and sustainable building practices in affordable housing design. It integrates materials and methods that promote environmental quality, economic vitality and social benefits through design, construction and operation of the built environment. Green Communities aligns affordable housing investment strategies with environmentally responsive building practices [6].

The Leadership in Energy and Environmental Design (LEED) Green Building Rating System was created by the U.S. Green Building Council (USGBC) to establish a "common standard of measurement" for "green" buildings. LEED attempts to define a term that is often considered indefinable--sustainability. USGBC members determine those elements that contribute to the sustainability of a building and promote LEED products and resources as a path to meet sustainable building goals [7].

Another tools called BRANZ Green Home Scheme, produced by the Building Research Association of New Zealand. BRANZ provides an assessment procedure , called the Green Home Scheme. It offers an environmental audit for new homes, rating a range of environmental, health and safety issues. The BRANZ Green Home Scheme offers a comprehensive, independent check of many issues in all, including: energy efficiency, the use of recycled materials, waste disposal methods, storage of hazardous materials, indoor pollutants and smoke detection systems. The assessment can be carried out through a number of participating architectural practices [8].

LEED, the used tools in the United States of America and BRANZ, the used tools in New Zealand are the most famous assessment tools that in use, Accordingly, the suggested assessing Egyptian tools will be formalized from these tools.

\subsection{A Brief Of LEED And BRANZ Development Tools}

Architects began to explore designs that focused on the long-term environmental impact of maintaining and operating a building, looking beyond the socalled "first costs" of getting it built in the first place. This approach has since been formalised in a number of assessment and rating systems, such as the LEED [9] (Leadership in Energy and Environmental Design) standards developed by the United States Green Building Council (USGBC) starting in 2000.

The LEED standards are intended to produce "the world's greenest and best buildings" by giving developers a straight forward checklist of criteria by which the greenness of a building can be judged. It is a self-assessing system designed for rating new and existing commercial, institutional, and high-rise residential buildings. It is a feature-oriented system where credits are earned for satisfying each criteria. Different levels of eco-building certification are awarded based on the total credits earned. The system is designed to be comprehensive in scope and simple in operation [10]. 
Points are awarded in various categories, from energy use (up to 17 points) to water-efficiency (up to five points) to indoor environment quality (up to 15 points); the total then determines the building's LEED rating. Extra points can be earned by installing particular features, such as renewable-energy generators or carbon-dioxide monitoring systems. A building that achieves a score of 39 points earns a "gold" rating; 52 points earns a "platinum" rating. A gold rated building is estimated to have reduced its environmental impact by $50 \%$ compared with an equivalent conventional building, and a platinum-rated building by over $70 \%$. Rating buildings in this way reveals how inefficient traditional buildings and building processes are.

Another scheme of eco-assessment is established in New Zealand called BRANZ scheme [8]. BRANZ is an organization that introduces a method of ecoassessing New Zealand domestic building design. It conducted a survey in early 2003 to provide feedback on how the eco-building scheme is currently operating. Twelve building-related environmental issues were presented as a questionnaire that designed by BRANZ. Respondents asked to rank their relative importance into three categories: "very important", "important", and "not important". There was almost unanimous agreement that passive solar design techniques were "very important", there were four other issues, however, respondents saw as being at least "important". They were: ecobuilding material, water economy and efficiency, indoor air quality and toxicity of wood preservatives as shown in figure 2.

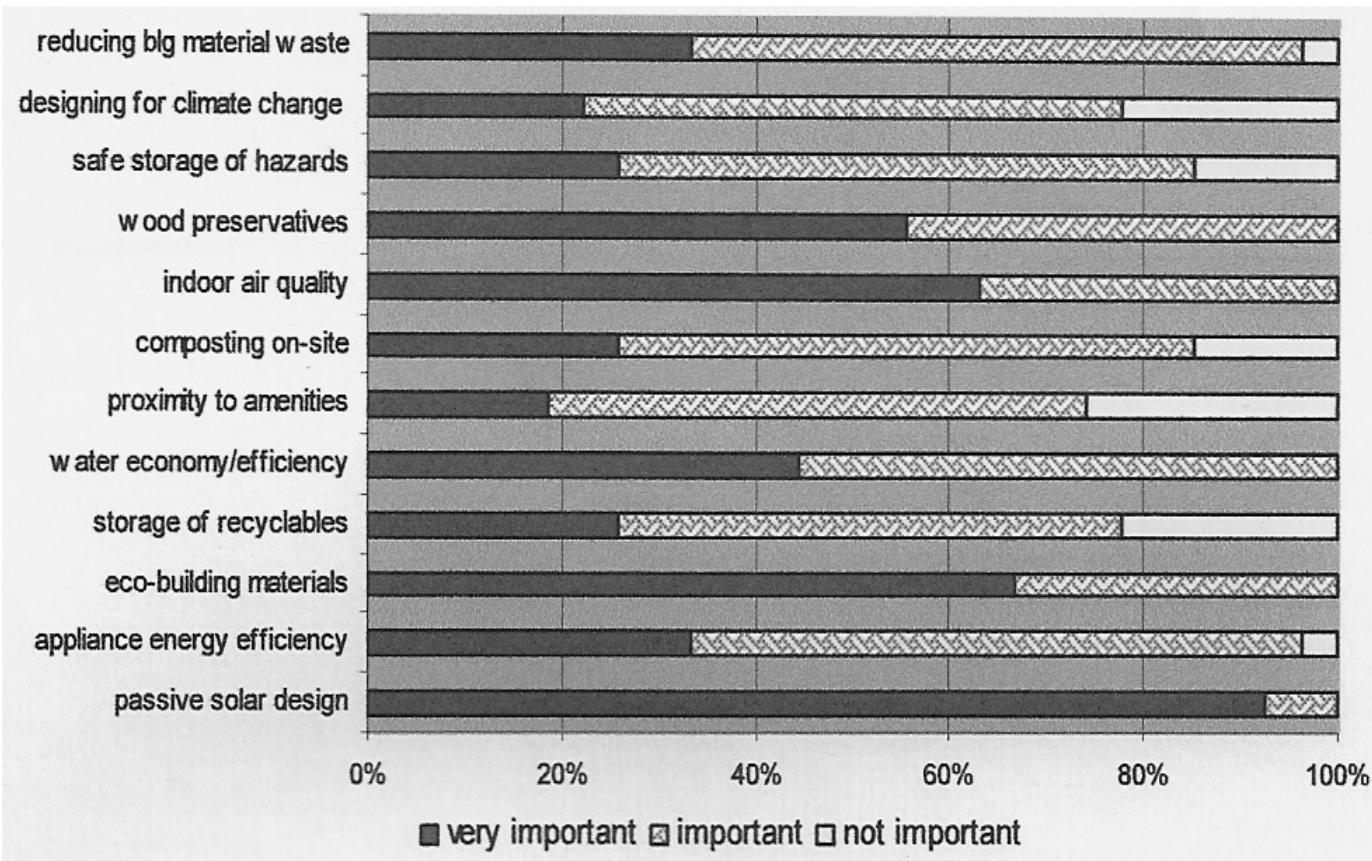

Figure 2: The eco-building criteria issues in creating and eco-home are classified to very important, important and not important according to BRANZ scheme [8]. 


\subsection{Stages In Delivery The Egyptian Eco-Assessing Tools}

The new tool which holds interest for Egypt should be developed and designed to help architects, builders and developers to evaluate the performance of qualifying eco-issue in their projects. The proposed tool is suggested to be launched as a web-tool, which will be applicable to all common types of buildings to encourage developers to address environmentally appropriate energy, water efficiency, building materials and landscaping. The key components that make this tool particularly attractive supposed to be as follow:

1- Very practical and supported by easy data, making it more friendly.

2- Easy updating of data.

3- Fast and easy remote assessment of projects.

4- Able to rate a range of development proposals.

5- Flexible, able to be easily adapted for regional differences.

6- Reduced environmental and social impact of housing development.

7- Connected with all the interested sources and organizations that can interact with the user and supply him/her with the required knowledge and advice.

Crosbie. [11] introduces a collection of environmentally-sensitive buildings, include building sitting, day lighting, wastewater, energy-saving, indoor air quality, and thermally insulated building envelopes. Accordingly, the basic data that suggested being available in the tool as a starting is suggested to include the following:

- Site: Recognises the sustainability benefits of urban renewal and encourages minimal site disturbance while maximising landscape.

- Social: Promote affordable, adaptable and accessible housing.

- Transport: Encourages a reduction in car-parking provision where good public transport is available and accessible. Promotes safe and accessible facilities for all walking, cycling and public transport users.

- Water: Recognizes the reduction in potable water demand associated with the application of water efficient fitting and appliances. Recognizes value of substituting mains potable water with harvested or recycled water, where appropriate.

- Energy: Recognizes the reduction in energy use and eco-house gas emissions associated with the application of energy-efficient fitting and appliances. Promotes the use of renewable energy.

- Waste and Recycling: Promotes waste minimisation through well designed developments. Promotes reuse and recycling of materials.

- Materials: recognizes the environmental impact associated with production, transport and use of building materials. Encourages material reuse and recycling.

- Indoor Amenity: Promotes naturally ventilated and lighting systems. Encourages material selection that minimises indoor air pollution.

Note: The previous data are the most important aspects that should be available to fulfil eco-building scheme. Using more data is depending on the understanding and the awareness of the developers, decision makers and the community.

Each building to be ranked by a certificate that evaluates it in the vision of ecohome scheme. The previous examined criteria can be described in brief as shown in table 1. 
Table 1: Suggested aspects to be qualified in the eco-assessing tool for Egypt.

\begin{tabular}{|c|c|}
\hline Major examined issues & Category achieved \\
\hline Energy consumption & $\begin{array}{l}\text { - } \quad \text { ery good level of thermal insulation } \\
\text { - } \quad \text { Eenewable energy assisted hot water } \\
\text { Effient lighting in main areas }\end{array}$ \\
\hline Sustainable materials & - Use of recycled materials \\
\hline Water economy & $\begin{array}{l}\text { - Self harvesting water } \\
\text { - Water reducing plumping }\end{array}$ \\
\hline Indoor air quality & $\begin{array}{l}\text { - Well vented bathroom } \\
\text { - Well vented kitchen }\end{array}$ \\
\hline Waste and recycling & - Promotes waste minimisation \\
\hline Transport & $\begin{array}{l}\text { - Encouraging public transportation } \\
\text { - Promotes safe and accessible facilities }\end{array}$ \\
\hline Social & $\begin{array}{l}\text { - Promote affordable, adaptable and } \\
\text { accessible housing }\end{array}$ \\
\hline Site & $\begin{array}{l}\text { - Recognises the sustainability benefits in } \\
\text { the site }\end{array}$ \\
\hline
\end{tabular}

According to table 1, the eco-home aspects can be calculated as weights. The evaluation of building depends on how much the major examined issues are applied to qualify the eco-scheme. The weight of the examined issues can be formalized using BRANZ [8] survey results in figure 2 and LEED [9] standard as a guide. According to the priority of the eco-building criteria in the previous two schemes, the weight can be classified into three categories: very important, important and required. If the suggested categories are transferred to points according to its priorities, the very important issues got 10 points, the important issues got 8 points and the required issues got 5 points as an example, the examined issues can be organized to be as shown in table 2.

Table 2: Transforming the major examined eco-issues into points.

\begin{tabular}{|l|c|}
\hline \multicolumn{1}{|c|}{ Major examined issues } & The weigh as points \\
\hline Energy consumption & 10 \\
\hline Sustainable materials & 10 \\
\hline Indoor air quality & 10 \\
\hline Water economy & 8 \\
\hline Waste and recycling & 8 \\
\hline Site & 5 \\
\hline Social & 5 \\
\hline Transport & 5 \\
\hline Total points & $\mathbf{6 1}$ \\
\hline
\end{tabular}


Extra points can be earned by installing particular features, such as renewableenergy generators or carbon-dioxide monitoring systems. Accordingly, building can be classified as platinum, gold and bronze rate.

According to the previous classification, each building will be evaluated concern qualifying the eco-criteria to get the rank and will has a certificate that certified what is the rank is the building is located and its category concern qualifying the eco-building scheme, which of course will effect of the construction market price.

The developer can evaluate the construction within each stage of the design process. This processing gives him/her a conclusion around the category that the building is located, and the opportunity to enhance the building performance in each stage. The suggested form of this process is shown in table 3.

Table (3): The suggested strategy for evaluating major examined eco-issues at the different stages of building design stage.

\begin{tabular}{|c|c|c|c|c|c|}
\hline & $\begin{array}{c}\text { Master } \\
\text { planning }\end{array}$ & $\begin{array}{c}\text { Pre-design } \\
\text { stage }\end{array}$ & $\begin{array}{c}\text { Design } \\
\text { development }\end{array}$ & $\begin{array}{c}\text { Construction } \\
\text { documents }\end{array}$ & $\begin{array}{c}\text { Post } \\
\text { construction }\end{array}$ \\
\hline $\begin{array}{c}\text { Energy } \\
\text { consumption }\end{array}$ & & & & & \\
\hline $\begin{array}{c}\text { Sustainable } \\
\text { materials }\end{array}$ & & & & & \\
\hline $\begin{array}{c}\text { Indoor air } \\
\text { quality }\end{array}$ & & & & & \\
\hline $\begin{array}{c}\text { Water } \\
\text { economy }\end{array}$ & & & & & \\
\hline $\begin{array}{c}\text { Waste and } \\
\text { recycling }\end{array}$ & & & & & \\
\hline Site & & & & & \\
\hline Social & & & & & \\
\hline Transport & & & & & \\
\hline Total points & & & & & \\
\hline Rating & & & & & \\
\hline
\end{tabular}

\subsection{Proposed Action To Practice The Egyptian Eco-Assessing Criteria}

- Rating buildings is the way of revealing how efficient traditional buildings and building processes are. The Egyptian eco-building strategies will serve in improving the natural environment. In the past, the construction industry in Egypt was very slow to change and to encourage designers and owners to fulfil ecobuilding since a huge transformation in this industry is unlikely. Now, the construction industries are ready to serve an important role in demonstrating ecobuilding strategies, proving their strengths, and identifying their weaknesses.

- Design teams and owners have to give special attention to environmental concerns as well as occupant satisfaction by incorporating more natural daylight and the different aspects of eco-building. 
- Eco-building design and strategies have been reported in different countries to have numerous benefits for the environment, as well as building occupants and organizations. Building professionals can have significant positive impacts on the environment by adopting design and construction practices that minimize environmental degradation, or perhaps serve a restorative function.

- Government, local authorities, other large institutions, such universities, and companies can have a major influence on establishing eco-assessing tool in Egypt. Private firms similar to public organizations, also have to work to improve the environmental performance of their operations, products and services. They have to use the assessing eco-building tools to identify the materials in their products that affect the significant environmental, health and safety risks.

- The establishment of an association of university educators and practitioners in architecture and related disciplines who support excellence in the teaching of environmental science and building technologies is very necessary. In other words, it supports knowledge for people involved with eco-building research, education and technology transfer. This plan can be supported in a number of practical ways, such as planning programs that focuses on the sharing of teaching methods and tools; accordingly, we need to run national teacher training workshops and continuing education seminars.

- As the profession gains experience with producing eco-buildings, a pool of talented young professionals with enough real-world experience to be credible in both the studio and classroom should now be emerging. It is very useful to reach out to this cadre of young professionals, and to encourage architectural firms to mentor young professionals in ways that might prepare them to take on academic positions.

\section{CONCLUSION}

Establishing true eco-building tools as targets for measuring and evaluating our environmental impact is not fantasy. It has been done and used in Europe, United States of America and many other countries long time ago. Increasing the awareness about community, and economic benefits of buildings leads to promoting the design, construction and operation of buildings and landscapes. In Egypt, the establishing of eco-building will be the fastest growing environmentally focused building activities.

A number of eco-building programs have been established or proposed, all with a general theme of promoting the design and construction of buildings that will have a positive impact on the environment. It's difficult to argue with the objective of building environmentally friendly structures. But it's not easy to qualify eco-building. In Egypt, it is necessary to establish new eco-assessing tools that able to encouraging the qualifying the eco-building by the right way. This tool considers as a new system of values, a system which recognizes the organic unity between human and nature. Government should working with designers, developers, and operators of different projects to encourage the adoption of eco-building strategies and materials. Project developers and operators gain both directly and indirectly through higher quality, more efficient, and more durable projects.

This piece of work introduces the idea of implementing eco-building tools to be used in Egypt in form of categories. Each category is reflected the performance and 
how much the building is qualifying the eco-scheme. According to the previous, the goal of establishing Eco-Building Program can be briefed at the following points:

- to encourage construction and demolition waste reduction in public and projects.

- to promote environmentally preferred building concepts, techniques and materials.

The components of the program include:

- Tool Kit Development and Distribution (to local authorities, town government, non-profit organizations and contractors).

- Technical Support to Public Projects.

- Construction Project Rating System.

- Web Site Development.

- Special Events (displays, seminars, demonstrations).

\section{REFERENCES}

[1] Davey, P., Who's Responsible? Architectural Review magazine, copyright 1997 EMAP Architecture, p. 5. July, 1997.

[2] http://www.greenbuildingsbc.com/new_buildings/definition.html, (last accessed $20^{\text {th }}$ February, 2006).

[3] Jason Frederick McLennan, Green Architecture: A Definition, Solar Incidents, The newsletter of The Solar Information Center, University of Oregon, Vol. 7 No. 1, Fall 1996.

[4] http://www.environmentalchoice.com/English/ECP\%20Home/, (last accessed $19^{\text {th }}$ March, 2006).

[5] Herbert Hamele, Tourism Sustainability Certification Systems in Europe: The Challenge for Different Stakeholders, Puplic-Private Partenerships for Sustainability of Tourism Activities, WTO conference, 17-20 October 2004, Marianske Lazne, Czech Repuplic.

[6] www.americastreet.com/services/GreenCriteria.pdf, (last accessed $19^{\text {th }}$ March, 2006).

[7] http://www.agc.org/page.ww?section=Green+Construction\&name=LEED+Gree n+Building+Rating+System, (last accessed $19^{\text {th }}$ March, 2006).

[8] Study Report No. 134(2004), Review of the BRANZ, Green Home Scheme, BRANZ 2004, ISSN: 0113-3675.

[9] http://www.usgbc.org/DisplayPage.aspx ?CategoryID=19, (last accessed $10^{\text {th }}$ February, 2006), U.S. Green Building Council, 1015 18th Street, NW, Suite 508, Washington, DC 20036, USA.

[10] http://www.lrkimball.com/Architecture\%20and\%20Engineering/ae_experience_ green_leed.htm, (last accessed $10^{\text {th }}$ February, 2006)

[11] Crosbie, Michael J. Green Architecture: A Guide to Sustainable Design. Washington, DC: American Institute of Architects Press, 1993. 


\title{
دمج قيم المبني الايكولوجي خلال عملية التصميم: تقديم معيار للتقييم في مصر في عملة
}

\author{
حاتم جلال عبد العظيم ابراهيم

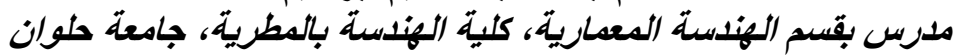

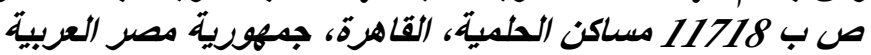 \\ hatem_ibrahim@hotmail.com بريد الكترونية
}

الأداء الجيد للعمارة الخضر اءه يوفر أداء متميز وظيفيا والاستغلال الأمثل للطاقة و المياه،

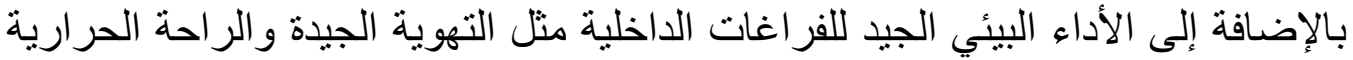

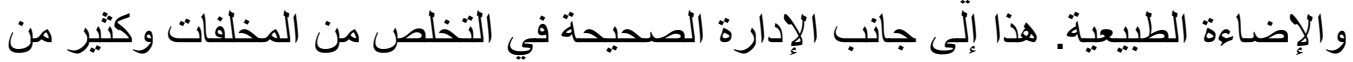

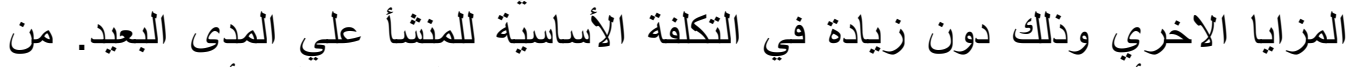

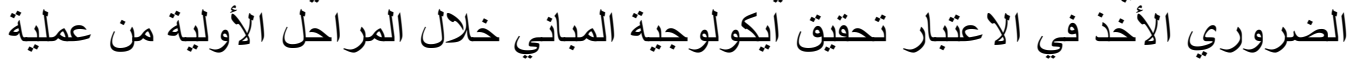

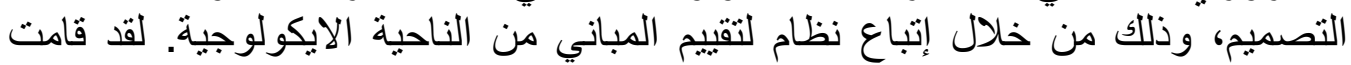

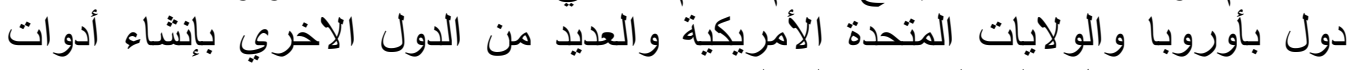

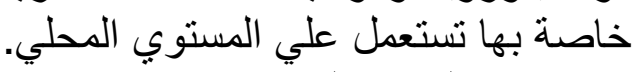

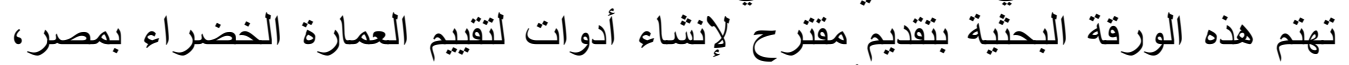

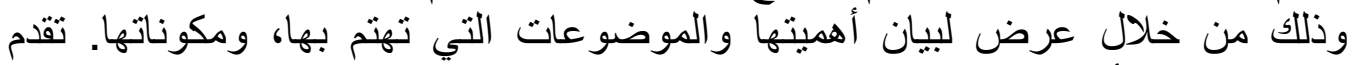

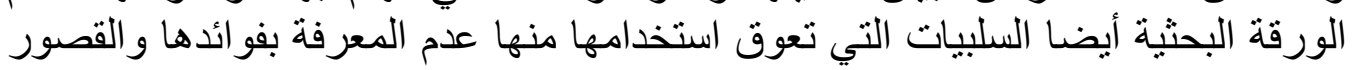

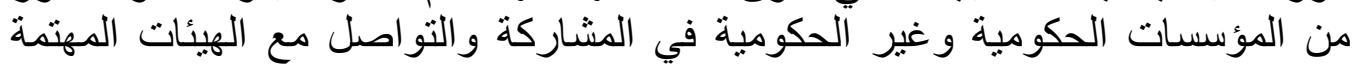

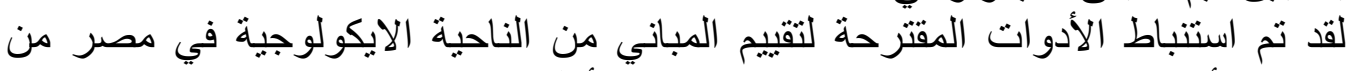

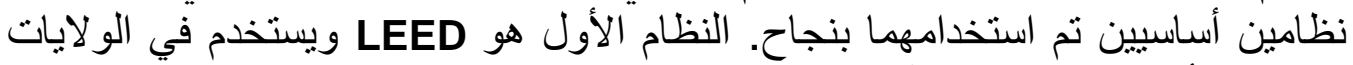

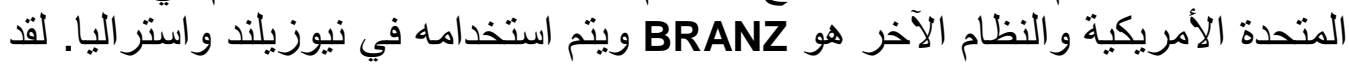

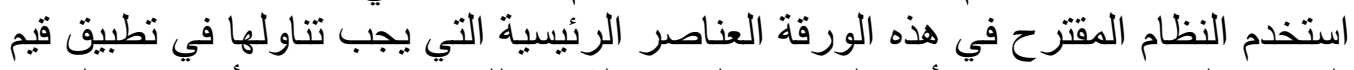

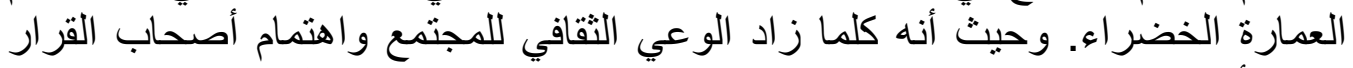

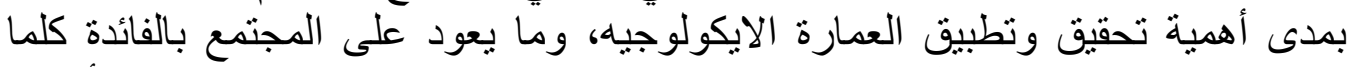

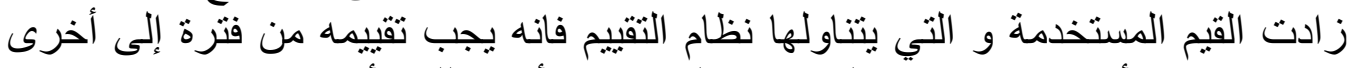
مع إضافة قيم أخرى مما يؤدي إلى زيادة المستوى الأدائي للمنشأ. 